\title{
EFFECTIVENESS OF ROBUSTA COFFEE BEAN EXTRACT GEL ON COLLAGEN FIBERS DENSITY IN POST-GINGIVECTOMY WOUND HEALING
}

Tantin Ermawati*, Happy Harmono*, Dania Kartikasari*

* Departemen Biomedik Fakultas Kedokteran Gigi Universitas Jember

Correspondence: tantin.ermawati@unej.ac.id

Keywords:
Gingivectomy, coffee
bean, collagen, wound
healing

\section{ABSTRACT}

Background: Gingivectomy is a periodontal surgical procedure that eliminates excess gingival tissues by excision, usually to remove a gingival pocket which leads to scars and recontours the gingival to its proper anatomical form. Wound healing is a process to restore the missing functions and structures of a tissue due to injuries or inflammations. Robusta coffee bean contains many bioactive compounds that can accelerate the wound healing process. The study aimed to determinate the effectiveness of robusta coffee bean extract gel with concentration $40 \%, 50 \%, 60 \%$ on collagen fibers density in post-gingivectomy wound healing

Method: 36 Wistar rats were divided into 9 groups: control, gingivectomy without therapy, gingivectomy $+40 \%$ robusta coffee bean extract gel, gingivectomy $+50 \%$ robusta coffee bean extract gel, and gingivectomy $+60 \%$ robusta coffee bean extract gel. The last 4 groups were divided again into day 3 and 7 euthanasia. The results were processed by Trichrome Mallory to visualized the collagen fibers and then measured by ImageJ software.

Result: Robusta coffee beans extract gel therapy with concentration $40 \%, 50 \%$ and $60 \%$ had higher average collagen fibers density compared to group without therapy.

Conclusion: Robusta coffee bean extract gel increased the density of collagen fibers in post-gingivectomy wound healing

\section{PENDAHULUAN}

Gingiva adalah bagian dari mukosa mulut yang memiliki fungsi utama sebagai perlindungan pertama rongga mulut, sehingga membuat gingiva mudah terkena luka ${ }^{1}$. Luka pada gingiva salah satunya dapat disebabkan oleh perawatan pasca bedah gingivektomi ${ }^{2,3}$. Gingivektomi adalah teknik bedah periodontal dengan cara mengeksisi jaringan gingiva yang membesar sehingga mendapatkan bentuk anatomis yang baru dan menghilangkan poket gingiva yang mengakibatkan suatu jejas luka. Penyembuhan luka merupakan proses biologis makhluk hidup untuk mengembalikan struktur dan fungsi suatu jaringan akibat dari cidera atau inflamasi ${ }^{4,5}$. Proses penyembuhan luka pada rongga mulut memerlukan waktu yang lebih cepat. Proses penyembuhan luka terdiri dari tiga fase yang saling terintegrasi yaitu inflamasi, proliferasi, dan remodelling ${ }^{6,7}$. Proses penyembuhan luka dapat dilihat dari berbagai indikator, salah satunya adalah kepadatan serabut kolagen. Pada proses penyembuhan luka, kolagen dibentuk sejak hari ke-3 dan akan tampak nyata jumlahnya di hari ke-7 setelah luka 7,8 .

Kepadatan kolagen merupakan salah satu parameter dan indikator penting dalam proses penyembuhan luka ${ }^{9,10}$. Kolagen yang terbentuk akan membentuk jaringan ikat yang menghubungkan tepi-tepi luka dengan erat serta dengan adanya kolagen dapat meningkatkan pertautan antar jaringan baru sehingga dapat memperkuat area penyembuhan ${ }^{11}$.

Bahan yang dijual di pasaran yang biasa digunakan untuk membantu proses penyembuhan 
luka pasca gingivektomi adalah Periodontal Dressing. Kelemahan Periodontal Dressing yaitu ketika digunakan oleh pasien akan kurang nyaman, harus dilakukan penggantian berkala oleh dokter gigi serta harganya cenderung mahal ${ }^{1}$. Oleh karena itu saat ini perlu dikembangkan alternatif pemanfaatan tanaman herbal. Penggunaan tanaman herbal diharapkan dapat mempercepat proses penyembuhan luka dengan efek samping minimal12. Salah satu tanaman yang dijumpai di Indonesia adalah kopi. Salah satu jenis tanaman kopi yang paling banyak di Indonesia ialah kopi robusta (Coffea canephora) ${ }^{4}$.

Kopi robusta mengandung beberapa bahan aktif diantaranya polifenol, flavonoid, kafein, kumarin, asam klorogenat, saponin trigonelin dan tokoferol $^{4,13}$. Flavonoid memiliki efek anti inflamasi dan bekerja dalam meningkatkan penyembuhan luka gingiva tikus Sprague Dawley dengan mempercepat laju epitelisasi melalui induksi produksi transforming growth factor (TGF)-beta. Asam klorogenat, kafein dan saponin dalam kopi robusta memiliki sifat antioksidan yang mampu meningkatkan penyembuhan luka dengan cara menetralkan radikal bebas yang terbentuk saat proses penyembuhan luka ${ }^{14}$.

Pemberian obat pada proses penyembuhan luka gingiva bisa secara oral maupun topikal. Salah satu bentuk sediaan topikal adalah gel. Pemberian obat secara topikal bersifat lebih selektif di bagianbagian yang spesifik, dapat dilakukan sendiri oleh pasien, serta mudah dilakukan penghentian obat jika diperlukan ${ }^{15}$. Penelitian ini bertujuan untuk melihat efektifitas gel ekstrak biji kopi robusta (Coffea canephora) konsentrasi 40\%, 50\% dan $60 \%$ dalam peningkatan kepadatan serabut kolagen pada proses penyembuhan luka gingiva.

\section{METODE PENELITIAN}

Penelitian ini merupakan penelitian experimental laboratories pada tikus wistar jantan menggunakan the post test only control group design. Penelitian dilakukan di laboratorium Biomedik FKG Universitas Jember (UNEJ), laboratorium Farmasetika Fakultas Farmasi UNEJ dan Laboratorium CDAST UNEJ menggunakan subjek sebanyak 36 ekor tikus wistar jantan. Subjek diadaptasi selama 1 minggu diberi makanan dan minum standar (ad libitium). Subjek dibagi menjadi 9 kelompok, yang dieutanasia pada hari ke-3 dan ke-7 dengan 4 subjek pada masing-masing kelompok. Penelitian ini telah mendapat persertujuan dari Komisi Etik Penelitian di Fakultas Kedokteran Gigi UNEJ.

\section{Tahap persiapan dan pembagian hewan coba}

Hewan coba dibagi menjadi 9 kelompok yaitu K (kontrol) yakni kelompok yang tidak diberi perlakuan gingivektomi dan di eutanasia pada hari ke-3, P- adalah kelompok gingivektomi tanpa terapi dan dieutanasia pada hari ke-3 dan ke-7, P40\% adalah kelompok gingivektomi yang diterapi gel ekstrak biji kopi robusta $40 \%$ dan dieutanasia pada hari ke-3 dan ke-7, P50\% adalah kelompok gingivektomi yang diterapi gel ekstrak biji kopi robusta $50 \%$ dan dieutanasia pada hari ke-3 dan ke-7, P60\% adalah kelompok gingivektomi yang diterapi gel ekstrak biji kopi robusta $60 \%$ dan dieutanasia pada hari ke-3 dan ke-7.

\section{Pembuatan Gel ekstrak biji kopi robusta}

Kopi robusta didapatkan dari perkebunan kopi desa Sidomulyo, kecamatan Silo, kabupaten Jember. Sampel biji kopi kering dihaluskan menggunakan pencacah kopi hingga menjadi serbuk dan ditimbang sebanyak 1000 gram, selanjutnya dilakukan maserasi dalam larutan 
etanol 96\% selama 72 jam. Proses ekstraksi menggunakan pelarut etanol hingga diperoleh ekstrak pekat $100 \%$. Pembuatan basis gel dimulai dengan CMC 2 gram dikembangkan dalam $98 \mathrm{ml}$ air dengan suhu $70 \stackrel{\circ}{\circ}$ dalam mortar selama 15 menit. Kemudian diaduk sampai terbentuk sediaan berwarna jernih. Selanjutnya, sediaan diaduk hingga homogen dan terbentuk massa gel. Masukkan ekstrak biji kopi robusta menjadi konsetrasi $40 \%, 50 \%$ dan $60 \%$ kedalam mortar dan dicampur hingga homogen.

\section{Prosedur gingivektomi tikus wistar}

Hewan coba dianestesi dengan ketamin dengan dosis $0,0875-0,1 \mathrm{ml}$ dan Xylazene dengan dosis $0,04-0,05 \mathrm{ml}$. Prosedur gingivektomi dilakukan pada gingiva regio molar 1 kiri rahang bawah. Sebelum gingivektomi, dilakukan pengukuran terlebih dahulu secara vertikal dan horizontal. Panjang vertikal ditentukan $1 \mathrm{~mm}$ dari margin gingiva ke apikal dan horizontal ditentukan dari lebar mesial distal gigi molar satu. Kemudian dilakukan pemotongan gingiva pada kelompok perlakuan dengan menggunakan blade scalpel membentuk sudut $45^{\circ}$ dengan permukaan gigi.

\section{Aplikasi Topikal Gel Ekstrak Biji Kopi Robusta}

Tikus yang telah dilakukan gingivektomi selanjutnya dilakukan aplikasi topikal gel ekstrak biji kopi robusta dengan konsentrasi 40\% (P40\%), konsentrasi 50\% (P50\%), dan konsentrasi 60\% (P60\%). Gel tersebut diaplikasikan pada gingiva regio molar satu bawah kiri menggunakan disposible syringe yang telah diambil jarumnya dengan dosis $0,05 \mathrm{ml}$. Aplikasi topikal gel dilakukan dua kali dalam sehari selama 3 hari dan 7 hari3i,16. Setelah pengaplikasian, gel dibiarkan agar bahan tidak larut dengan tidak memberi makan dan minum pada hewan coba selama 15-30 menit.

\section{Eutanasia Subjek}

4 ekor tikus wistar dalam setiap kelompok dilakukan eutanasia pada hari ke-3 dan ke-7. Dilakukan pengambilan jaringan pada bagian molar satu sampai molar 3 rahang bawah kiri. Setelah itu subjek dimasukkan ke dalam buffer formalin selama 24 jam agar jaringan yang akan diamati tidak rusak.

\section{Tahap Histologis dan Pengamatan Serabut Kolagen}

Subjek yang telah difiksasi ke dalam buffer formalin selama 24 jam kemudian didekalsifikasi menggunakan asam format $10 \%$ selama 21 hari supaya subjek lebih lunak. Subjek yang telah lunak kemudian dilakukan prosedur histologi jaringan meliputi proses dehidrasi, clearing, impregnansi, embedding, dan pemotongan jaringan secara bukolingual. Selanjutnya dilakukan pewarnaan subjek menggunakan Tricrome Mallory. Pengamatan serabut kolagen menggunakan mikroskop binokuler dengan perbesaran 400x dengan cara melakukan pengukuran kepadatan daerah yang berwarna biru pada gingiva yang mengalami penyembuhan menggunakan software ImageJ pada 3 lapang pandang terpilih kemudian hasilnya dijumlah dan dirata-rata.

Pembacaan preparat serabut kolagen dengan kriteria penilaian berdasarkan skor, yaitu:

0 :Tidak tampak gambaran serabut kolagen

1 :Serabut kolagen terlihat tipis atau sedikit sekali

2 :Serabut kolagen terlihat menyebar tipis

3 :Serabut kolagen terlihat menyebar tebal

4 :Serabut kolagen terlihat mengumpul tebal.

\section{HASIL PENELITIAN}

Gambaran histologis kepadatan serabut kolagen kelompok yang dieutanasia pada hari ke-3 
ditunjukkan pada Gambar 1, gambaran histologis kepadatan serabut kolagen kelompok yang dieutanasia pada hari ke-7 ditunjukkan pada Gambar 2 sedangkan rata-rata kepadatan serabut kolagen ditunjukkan pada Gambar 3. Data yang diperoleh dilakukan uji normalitas menggunakan Kolmogorov Smirnov dan uji homogenitas menggunakan uji Levene dengan $p>0,05$. Hasil menujukkan data terdistribusi normal dan homogen.

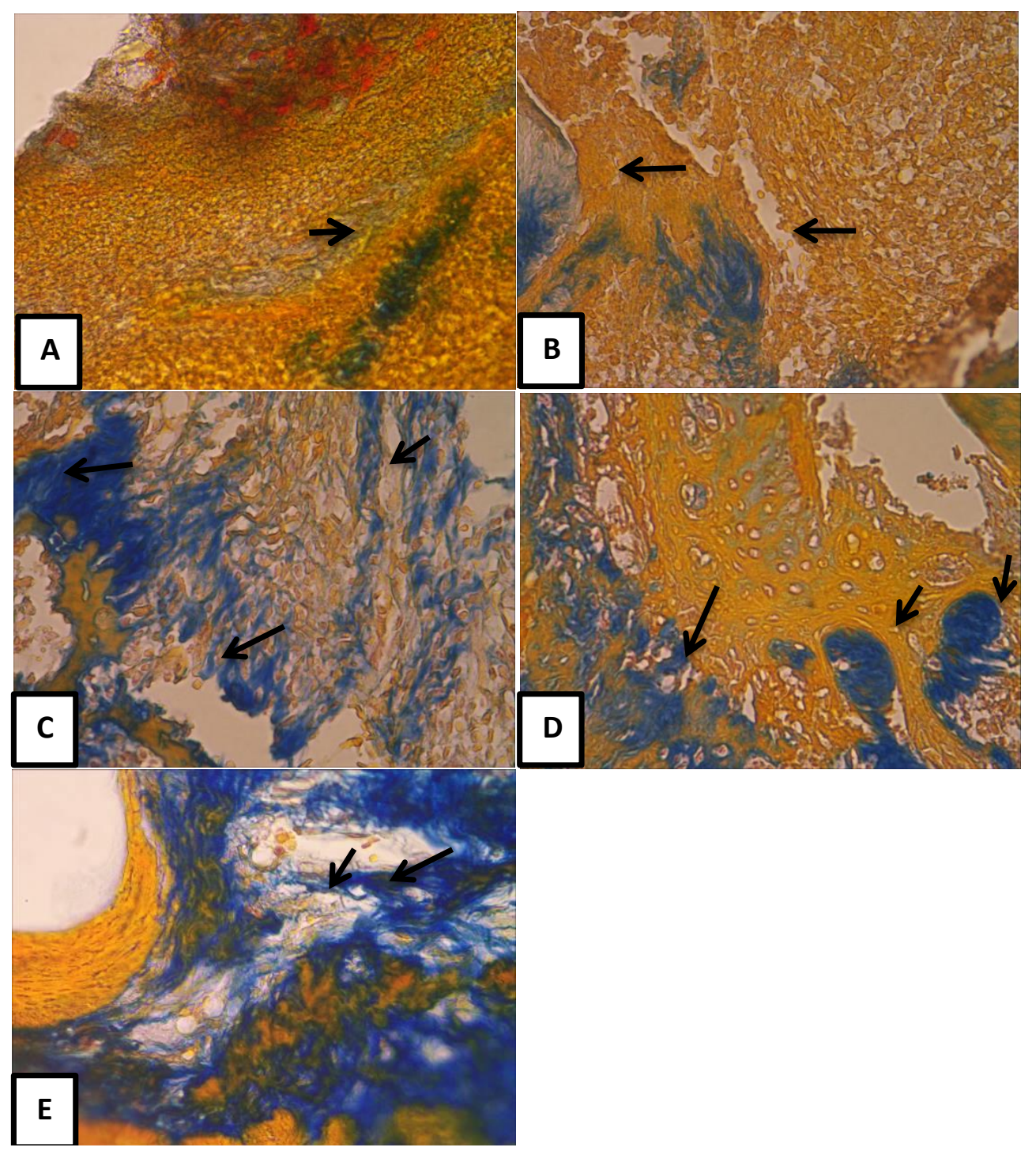

Gambar 1. Gambaran histologis serabut kolagen dengan pewarnaan Tricrome Mallory dengan perbesaran 400x pada hari ke-3 pasca gingivektomi. Tanda panah hitam menunjukkan serabut kolagen. (A) kelompok perlakuan gingivektomi tanpa terapi, (B) kelompok perlakuan gel ekstrak biji kopi robusta 40\%, (C) kelompok perlakuan gel ekstrak biji kopi robusta 50\%, (D) kelompok perlakuan gel ekstrak biji kopi robusta $60 \%$, (E) kelompok kontrol. 


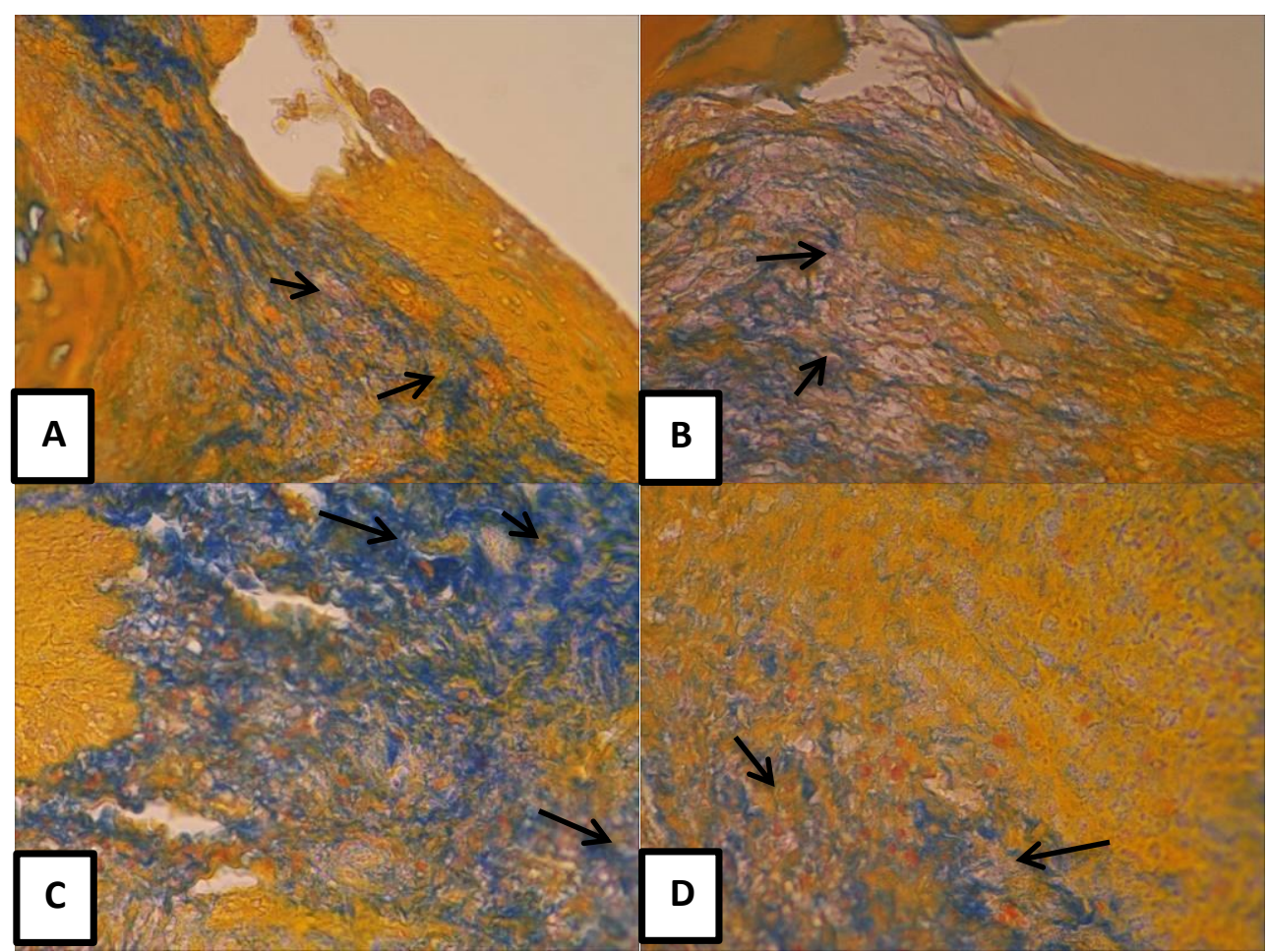

Gambar 2. Gambaran histologis serabut kolagen dengan pewarnaan Tricrome Mallory dengan perbesaran 400x pada hari ke-7 pasca gingivektomi. Tanda panah hitam menunjukkan serabut kolagen. (A) kelompok perlakuan gingivektomi tanpa terapi, (B) kelompok perlakuan gel ekstrak biji kopi robusta 40\%, (C) kelompok perlakuan gel ekstrak biji kopi robusta 50\%, (D) kelompok perlakuan ael ekstrak biii kopi robusta $60 \%$.

Tabel 1. Hasil rata-rata perhitungan kepadatan serabut kolagen pada tiap kelompok dalam satuan (pixel)

Kelompok Sampel

\section{Hari Ke-3}

(Rata-rata)

\section{Hari Ke-7 \\ (Rata-rata)}

\begin{tabular}{ccc}
\hline $\mathrm{K}$ & 48,123 & 48,123 \\
\hline $\mathrm{P}-$ & 4,997 & 12,209 \\
\hline P40\% & 8,936 & 23,681 \\
\hline P50\% & 12,402 & 26,400 \\
\hline P60\% & 10,768 & 23,779 \\
\hline
\end{tabular}




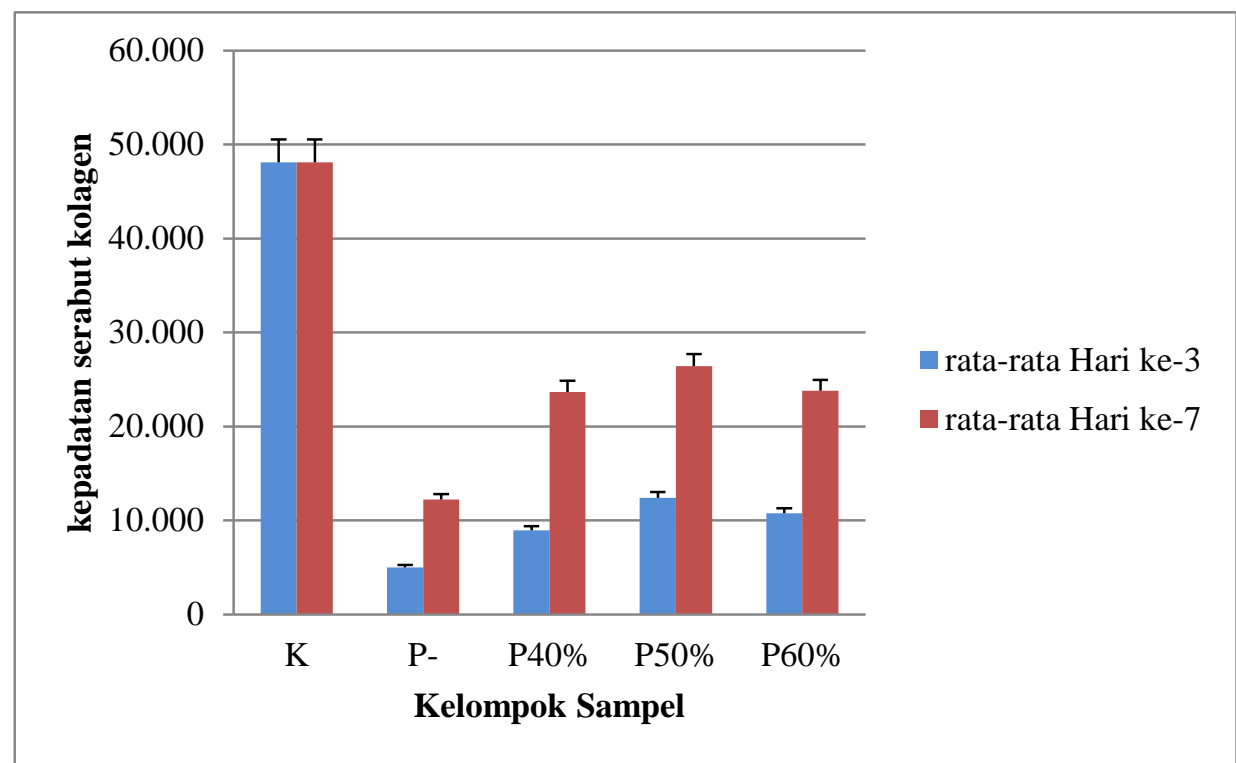

Gambar 3. Diagram rata-rata kepadatan serabut kolagen pada setiap kelompok. ${ }^{*} \mathrm{p}<0,05$ dibandingkan dengan kelompok gingivektomi tanpa terapi ( $\left.\mathrm{P}-\right)$.

\section{DISKUSI}

Penelitian ini bertujuan untuk mengetahui efektivitas pemberian aplikasi topikal gel esktrak biji kopi robusta terhadap peningkatan kepadatan serabut kolagen pada penyembuhan luka pasca gingivektomi pada tikus wistar. Hasil penelitian menunjukkan rata-rata kepadatan serabut kolagen paling tinggi adalah kelompok kontrol, hal ini karena kelompok kontrol merupakan kelompok normal sehingga tidak dilakukan perlakuan apapun. Pada kelompok perlakuan yang dieutanasia hari ke-3, yakni kelompok $\mathrm{P}$ - yang merupakan kelompok gingivektomi tanpa terapi rata-rata kepadatan serabut kolagen $(4,997)$ lebih rendah daripada kelompok perlakuan gingivektomi yang diterapi dengan gel ekstrak biji kopi robusta $40 \%, 50 \%$, dan $60 \%$. Hal ini karena adanya perbedaan terapi. Adanya terapi menggunakan gel ekstrak biji kopi robusta ini membantu mempercepat proses penyembuhan luka yang ditandai dengan semakin meningkatnya kepadatan serabut kolagen. Hal ini sesuai dengan penelitian sebelumnya bahwa kopi robusta dapat mempercepat penyembuhan luka karena beberapa senyawa diantarnya adalah kafein, asam klorongenat, flavonoid dan saponin ${ }^{14}$. Pada kelompok perlakuan hari ke-3, yakni kelompok P50\%3 yang merupakan kelompok gingivektomi yang diterapi gel ekstrak biji kopi robusta $50 \%$ memiliki rata-rata kepadatan serabut kolagen lebih tinggi $(12,402)$ daripada kelompok P40\% (8,936). Rata-rata kepadatan serabut kolagen terjadi penurunan pada konsentrasi $60 \%$ $(10,768)$. Hal ini dikarenakan adanya perbedaan konsentrasi gel ekstrak biji kopi robusta yang diberikan. Perbedaan konsentrasi gel ekstrak biji kopi robusta akan mempengaruhi perbedaan jumlah kandungan bahan aktif dan keefektifan gel dalam terapi penyembuhan luka ${ }^{17}$. Kandungan bahan aktif yang terlalu tinggi akan mempengaruhi dosis obat. Tubuh akan merespon efek terapeutik suatu obat pada dosis optimum, yang mana merupakan dosis terbaik obat untuk diberikan. Kemudian terdapat dosis maksimum yang 
merupakan dosis tertinggi yang masih bisa diberikan dan dapat menyembuhan, sedangkan jika dosis sudah melebhi dosis maksimum maka dosis tersebut menjadi dosis toksik yang merupakan takaran dosis yang jika diberikan akan menimbulkan kontradiksi dari efek terapeutik ${ }^{20}$.

$$
\text { Pada kelompok perlakuan yang }
$$
dieutanasia pada hari ke-7 memiliki rata-rata kepadatan serabut kolagen lebih tinggi daripada kelompok perlakuan yang dieutanasia pada hari ke3. Hal ini dikarenakan adanya perbedaan fase penyembuhan, kelompok pada hari ke-3 merupakan tahap proliferasi awal, kelompok perlakuan pada hari ke-7 yang merupakan puncak terbentuknya serabut kolagen pada fase proliferasi ${ }^{7}$. Kelompok perlakuan gingivektomi tanpa terapi yang dieutanasia hari ke-3 (P-3) memiliki kepadatan serabut kolagen yang lebih rendah dibandingkan kelompok perlakuan gingivektomi dan diterapi gel ekstrak biji kopi robusta $40 \%, 50 \%$ dan $60 \%$ yang dieutanasia pada hari ke-7. Hal ini karena kelompok P-3 dieutanasia pada hari ke-3 dimana merupakan tahap proliferasi awal, sedangkan P40\%7, P50\%7 dan P60\%7 dieutanasia pada hari ke-7 yang merupakan puncak terbentuknya serabut kolagen pada fase proliferasi. Selain itu adanya perbedaan terapi yakni pemberian gel ekstrak biji kopi robusta.

Data hasil uji beda menunjukkan bahwa terdapat perbedaan bermakna antar setiap kelompok. Hal tersebut sesuai dengan penelitian sebelumnya bahwa biji kopi robusta memiliki senyawa aktif yang dapat meningkatkan kepadatan serabut kolagen pada proses penyembuhan luka.

Biji kopi robusta mengandung zat flavonoid dan asam klorogenat yang berperan sebagai antiinflamasi. Flavonoid dan Asam klorogenat sebagai antiinflamasi bekerja dengan cara mengurangi efek histamin, bradikinin dan leukotrin ${ }^{18}$. Aktivitas antiinflamasi dari flavonoid dan asam klorogenat juga dapat mengahambat sikloogsigenase yang merupakan protein yang bertindak sebagai enzim khusus untuk mempercepat produksi prostaglandin. Penekanan mediator inflamasi menyebabkan berkurangnya nyeri dalam pembengkakan dan mengurangi terjadinya vasodilatasi pembuluh darah dan aliran darah lokal, sehingga migrasi sel radang pada area radang akan menurun. Selanjutnya reaksi inflamasi akan berlangsung lebih singkat dan memasuki tahap proliferasi ${ }^{9}$. Selain itu efek antiinflamasi ini juga dapat merangsang makrofag untuk menghasilkan growth factor seperti TGF- $\beta$ yang berfungsi menginduksi proliferasi dan migrasi fibroblast serta menginduksi fibroblas untuk mensintesis kolagen ${ }^{18}$.

Kopi memiliki kandungan antioksidan yang lebih banyak dari pada vitamin C. Kandungan bahan aktif seperti kafein dan saponin dalam kopi yang memiliki efek antioksidan juga berperan dalam mempercepat proses penyembuhan luka ${ }^{14}$. Aktivitas Antioksidan kafein dapat menetralkan radikal bebas dan menghambat radikal bebas yang timbul dalam proses penyembuhan luka. Pada proses inflamasi terjadi peningkatan infiltasi sel inflamasi yang akan menyebabkan mekanisme fagositosis terhadap antigen sehingga memicu radikal bebas. Radikal bebas yang diaktivasi oleh sel-sel inflamasi tidak hanya merusak sel yang terpapar alergen tetapi juga dapat merusak komponen-komponen matriks ekstraseluler ${ }^{18}$. Antioksidan dibutuhkan dan sangat penting untuk mencegah terjadinya kerusakan jaringan. Selain itu, antioksidan mencegah peningkatan produksi sitokin yang menyebabkan terjadinya proses inflamasi yang berlanjut. Oleh karena itu, terapi menggunakan antioksidan sangat diperlukan pada inflamasi kronis seperti penyembuhan luka ${ }^{19}$. 
Lama pemberian dapat berpengaruh terhadap hasil penelitian. Kepadatan kolagen merupakan salah satu parameter dan indikator penting dalam proses penyembuhan luka. Pada proses penyembuhan luka, kolagen dibentuk sejak hari ke-3 dan akan tampak nyata jumlahnya di hari ke-7 setelah luka. Pembentukan serabut kolagen dimulai pada hari ke-3. Fibroblas berubah membentuk matriks ekstraseluler dan mulai memproduksi tropokolagen pada hari ke-3. Fibroblas menyimpan tropokolagen yang nantinya akan diproduksi menjadi kolagen?. Pada hari ke-7 adalah hari puncak pada fase proliferasi dimana kolagen akan terakumulasi dan memberikan kekuatan pada daerah yang mengalami perlukaan. pada hari ke-7 pasca gingivektomi epitel akan mulai tumbuh seperti semula, diikuti penurunan jumlah sel radang disertai peningkatan jaringan ikat. Jaringan ikat yang baru terdiri dari sel-sel, kolagen dan serat-serat fiber. Kolagen utama yang diproduksi pertama kali pada jaringan granulasi adalah kolagen tipe III, namun dalam beberapa hari akumulasi kolagen tipe I meningkat dengan cepat dan mencapai puncak pada hari ke-7 sampai hari ke-14 pasca perlukaan dengan jumlah $75 \%$ dari total kolagen pada jaringan granulasi ${ }^{6}$.

\section{KESIMPULAN}

Berdasarkan hasil penelitian yang telah dilakukan dapat disimpulkan bahwa pemberian gel ekstrak biji kopi robusta dengan konsentrasi 40\%, $50 \%$ dan $60 \%$ secara topikal dapat meningkatkan kepadatan serabut kolagen pada proses penyembuhan luka pasca gingivektomi pada tikus Wistar. Perlu dilakukan penelitian lanjutan tentang hari pengamatan dari pemberian gel ekstrak biji kopi robusta selain hari pengamatan yang digunakan dalam penelitian dan mengenai gel agar tetap konsisten melekat dan terjaga dalam rongga mulut tikus wistar

\section{DAFTAR PUSTAKA}

1. Newman M G., Takei H.H., Klokkevold P.R., dan Carranza F.A.. Newman and Carranza's Clinical Periodontology 13th Edition. 2019. Canada: Elsevier.

2. Solanki G. A general overview of gingiva. IJBR. 2012;3:79 - 82.

3. Nofikasari I., Rufaida A., Aqmarina C.D., Failasofia, Fauzia A.R., et al.. Efek aplikasi topikal gel ekstrak pandan wangi terhadap penyembuhan luka gingiva. Majalah Kedokteran Gigi Indonesia. 2016;2: 53 - 59

4. Artho L.N., Wuisan J., dan Najoan J.A.. Efek Serbuk Kopi Robusta (Coffea canephora) Terhadap Penyembuhan Luka Insisi pada Kelinci (Oryctolagus cuniculus). Jurnal eBiomedik (eBm). 2015;3:743-748

5. Smith P.C., Caceres M., Martinez C., Oyarzun A., dan Martinez J. Gingival Wound Healing: An Essential Response Disturbed by Aging?. Journal of Dental Research. 2015;94:395-402

6. Larjava H. Oral Wound Healing : Cell Biology and Clinical Management Ed. 1. John Willey \& Sons Inc. United Kingdom. 2012;1:157.

7. Kumar V., Abbas K., dan. Aster J.C. Buku Ajar Patologi Robbins Edisi 9. Singapura: Elsevier Saunders. 2015.

8. Sabirin I.P.R, Maskoen M., dan Hernowo B.S. Peran Ekstrak Etanol Topikal Daun Mengkudu (Morinda citrifolia L.) pada Penyembuhan Luka Ditinjau dari Imunoekspresi CD34 dan Kolagen pada Tikus Galur Wistar. M.K.B. 2012;45:33226.

9. Naba'atin I, Wahyukundari M.A., dan Harmono H. Penambahan Ekstrak Kulit Buah Kakao (Theobroma cacao L.) Pada Periodontal Dressing Terhadap Kepadatan Kolagen Luka Gingiva Insisi. BIMKGI. 2015;3:28-38.

10. Raharyani H D, Istiati, dan Rahayu R.P.. Peran ekstrak gel daun melati (Jasminum sumbac) dalam peningkatan sabut kolagen pada penyembuhan luka sayat pada mencit (Mus musculus). Oral and Maxillofacial Pathology Journal. 2015;2:13-18.

11. Rangaraj A, Harding K., dan Leaper D. Role of Collagen in Wound Healing. Wounds. 2011;7:54-63.

12. Yanhendri dan Yenny, S.W. Berbagai Bentuk Sediaan Topikal dalam Dermatologi. C.D.K. 2012;39:423-30. 
13. Farhaty N, Muchtaridi. Tinjauan Kimia dan Aspek Farmakologi Senyawa Asam Klorogenat pada Biji Kopi : Review. Jurnal Farmaka Suplemen. 2016;14:1

14. Kenisa $Y$ P, Istiati, dan Wisnu S.J.. Effect of Robusta coffee beans ointment on full thickness wound healing. Dent. J. (Maj. Ked. Gigi). 2012;45:52-57

15. Singla V, Saini S., Joshi B., dan Rana A.C.. Emulgel: a New Platform for Topical Drug Delivery. I.J.P.B.S. 2012;3:486-98.

16. Ermawati T. Effects of Robusta Coffee Bean Extract (Coffea robusta) on the Viability of Neutrophils Exposed by Porphyromonas gingivalis. UNEJ e-Proceeding. 2016;169-172.

17. Fadlil N. I. P., Ermawati T., Hikmah N. Pengaruh Pemberian Gel Ekstrak Biji Kopi Robusta (Coffea Robusta) Terhadap Ketebalan Epitel Gingiva Pada Model Tikus Periodontitis
Yang Diinduksi Porphyromonas Gingivalis. Prosiding The 3th Dentistry Scientific Meeting of Jember. 2015;102-110.

18. Yuwono H. S. The New Paradigm of Wound Management Using Coffeee Powder. Global journal of surgery. 2014;2:2.

19. Ojeh N., Stojadinovic O., Pastar I., Sawaya A., Yin N., dan Tomic-Canic M. The effects of caffeine on wound healing. Int Wound J. 2014.

20. Parasuraman P. 2011. Toxicological sreening. J. Pharmacol Pharmacother. 2011;2:74-79.

21. Afiyah L.L, Ana M.. Efektifitas Gel Ekstrak Pithecellobium lobatum Benth. pada Proses Kesembuhan Luka Pasca Pencabutan Gigi Studi pada Cavia cobaya dengan Pengamatan Histologis. Mutiara Medika: Jurnal Kedokteran dan Kesehatan. 2017. 17(2):86-91. 